\title{
INDOOR EXPOSURE TO MOULD ALLERGENS
}

\author{
Ljerka PRESTER \\ Institute for Medical Research and Occupational Health, Zagreb, Croatia \\ Received in June 2011 \\ CrossChecked in December 2011 \\ Accepted in December 2011
}

\begin{abstract}
Humid indoor environments may be colonised by allergenic filamentous microfungi (moulds), Aspergillus spp., Penicillium spp., Cladosporium spp., and Alternaria spp. in particular. Mould-induced respiratory diseases are a worldwide problem. In the last two decades, mould allergens and glucans have been used as markers of indoor exposure to moulds. Recently, mould allergens Alt a 1 (Alternaria alternata) and Asp $\mathrm{f} 1$ (Aspergillus fumigatus) have been analysed in various environments (residential and occupational) with enzyme-linked immunosorbent assays, which use monoclonal or polyclonal antibodies. Household Alt a 1 and Asp f 1 levels were usually under the limit of the method detection. By contrast, higher levels of mould allergens were found in environments with high levels of bioaerosols such as poultry farms and sawmills. Data on allergen Alt a 1 and Asp f 1 levels in agricultural settings may provide information on possible colonisation of respective moulds and point out to mould-related diseases in occupants.
\end{abstract}

KEY WORDS: Alt a 1, Asp $f$ 1, A. alternata, A. fumigatus, ELISA, occupational exposure

Humans continuously inhale spores and fragments of allergenic moulds. Exposure to fungal allergens in outdoor and indoor environments might result in respiratory diseases in sensitive individuals (1). However, indoor exposure to mould allergens has not received due attention. This article gives a brief review of the findings of Alt a 1 (Alternaria alternata) and Asp $\mathrm{f} 1$ (Aspergillus fumigatus) as markers of mould exposure in various environments reported by us and other researchers.

\section{DISTRIBUTON OF MOULDS}

\section{Outdoor environments}

Generally, Cladosporium spp. and Alternaria spp. are the most common moulds outdoors worldwide (2-4). Fungal ecology is influenced seasonally, geographically, and by the diurnal cycle $(2,5)$. In Zagreb, Croatia, Alternaria spp. and Cladosporium spp. spores are detectable from May to November, peaking in the late summer (6). A similar seasonal pattern has been reported in other temperate European climates (7). On 17 days of August 2003, Zagreb air concentration of Alternaria spores exceeded the limit value of 100 spores per $\mathrm{m}^{3}$, which is associated with increased risk of allergy (8). This concentration of airborne moulds was influenced by meteorological conditions (temperature, humidity, solar radiation, wind, and rainfall). In the United Kingdom, Alternariarelated asthma has been reported in association with thunderstorms in the summer of 2002 (9). Alternaria spores can get dispersed over hundreds of miles from the source, especially in dry seasons. In addition, human activities, especially in agricultural settings can considerably contribute to the mould load in outdoor environments $(10,11)$.

\section{Indoor environments}

Healthy houses and buildings with low indoor humidity do not favour indoor fungal growth (10). 
Generally, the composition of indoor airborne fungi in healthy, non-mouldy houses resembles the composition of outdoor fungi (Alternaria and Cladosporium) $(2,12,13-15)$. Table 1 shows a marked difference between the distribution of moulds in healthy and sick/mouldy dwellings. It also shows currently thresholds for moulds in homes. In healthy indoor environments, indoor-to-outdoor mould ratio (I:O) is $<1(2,10,16)$. Shelton et al. (2) reported a median I:O in a US building of 0.16 . In contrast, in sick buildings the I:O ratio was $>1$, which points to considerable indoor sources of moulds. In damp buildings, moulds can grow and sporulate on the surface of the building material and in settled dust (15). Aspergillus versicolor is one of the most common moulds in damp buildings in European countries, the United States, and Canada (17). Pei-Chih et al. (13) reported an extremely high I:O ratio of 9.6 for Aspergillus in a suburban area of Taiwan. In indoor environments heavily contaminated with fungi, mould concentrations are usually up to three orders of magnitude higher than in healthy houses (Table 1). The highest fungal load has been detected in mouldcontaminated houses in New Orleans after Hurricane Katrina $(18,19)$. Based on previous studies, moulds are suggested as bioindicators of indoor air quality (10).

\section{Mould spores and fragments}

The aerodynamic size of the spores is typical for the species. The conidia of the Aspergillus spp. and Penicillum spp. (mostly $2 \mu \mathrm{m}$ to $5 \mu \mathrm{m}$ in diameter) are relatively small compared to the spores of Alternaria spp. (10 $\mu \mathrm{m}$ to $40 \mu \mathrm{m}$ in diameter $)(1,20)$. During sporulation, mould spores and hyphae are released into the air in a large number and inhaled (21). Generally, airborne mould spores with the aerodynamic diameter of $>10 \mu \mathrm{m}$ are deposited in the upper respiratory tract. They are associated with nasal and ocular symptoms (hay fever) $(22,23)$. On the other hand, particles in the range of $2 \mu \mathrm{m}$ to $10 \mu \mathrm{m}$, especially those $<5 \mu \mathrm{m}$, are respirable and can trigger allergic reaction. Laboratory-based studies have shown that moulds release into the environment large quantities of particles far smaller than spores $(0.03 \mu \mathrm{m}$ to $2 \mu \mathrm{m}$ in diameter) (24-27). This fragmentation of spores is caused by various physical and biological processes $(21-25,28,29)$. In two school buildings, the highest concentration of airborne fungal fragments was in the size range of $1.1 \mu \mathrm{m}$ to $4.7 \mu \mathrm{m}$. This indicates that smaller particles are very common, especially in damp buildings as opposed to healthy ones (30). Similarly, Gorny et al. (24) and Reponen et al. (29) demonstrated considerably higher levels of mould fragments than of intact spores in mouldcontaminated buildings. Inhaled ultrafine particles $(<1 \mu \mathrm{m})$ can penetrate deeply into the lung alveoli and make the respiratory symptoms and diseases even worse (28-30).

\section{ALLERGENS OF A. FUMIGATUS AND A. ALTERNATA}

Most fungal allergens have been identified from their conidia, hyphae, and small mycelial fragments $(24,31,32)$. All these particles contribute to exposure and allergic sensitisation in humans. Fungal allergens have been investigated systematically only in $A$. fumigatus, A. alternata, and Cladosporium herbarum $(22,33)$. Among more than 100 genera of fungal aeroallergens, $A$. fumigatus produces more allergenic molecules than other moulds (31-34). Table 2 lists $A$. fumigatus allergens recognised by World Health Organization and International Union of Immunological Societies (WHO/IUIS) Allergen Nomenclature Sub-

Table 1 Mould aerosols in healthy, sick, and flooded buildings

\begin{tabular}{lccccccc}
\hline Building & I:Oa & Dominant mould & $\begin{array}{c}\text { Total fungi } \\
\mathbf{c f u}^{-3}\end{array}$ & $\begin{array}{c}\text { Spores } \\
\text { per } \mathbf{~ m}^{\mathbf{3}}\end{array}$ & Mycotoxin & Stachybotrys & Ref. \\
\hline Healthy & $<1$ & Cladosporium & 10 to $10^{3}$ & $<1000$ & $\mathrm{nd}^{\mathrm{c}}$ & $\mathrm{nd}$ & 2,10 \\
\hline Sick & $\geq 1$ & $\begin{array}{c}\text { Penicillium, } \\
\text { Aspergillus }\end{array}$ & $>10^{3}$ & $>1300$ & detected & detected & $2,91,92$ \\
\hline $\begin{array}{l}\text { Flood- } \\
\text { affected }\end{array}$ & $>1$ & $\begin{array}{c}\text { Penicillium, } \\
\text { Aspergillus }\end{array}$ & $22 \times 10^{3}$ to $5 \times 10^{5}$ & $\begin{array}{c}82 \times 10^{3} \text { to } \\
63 \times 10^{4}\end{array}$ & detected & detected & 18,19 \\
\hline
\end{tabular}

andoor-outdoor mould ratio

${ }^{b}$ non-mouldy

cnot detected 
committee. Currently, the list refers to 23 molecules (35). Asp $\mathrm{f} 1$ (ribotoxin) is the main allergen and a critical factor in provoking allergic response (type I hypersensitivity) and bronchopulmonary aspergillosis (36-40). Asp $\mathrm{f} 1$ is a conserved protein, highly specific to A. fumigatus and not present in other members of the genus $(35,36,41)$. Recently, Asp f 34 has also been identified as a major allergen associated with sensitisation to Aspergillus (42). With the exception of Asp $\mathrm{f} 1$ and Asp $\mathrm{f} 5$ (metalloprotease), A. fumigatus allergens are homologous to the allergens of $A$. nidulans, A. oryzae, and other fungal species $(35,41)$. In addition, some allergens such as Asp f 11 and Asp f 27 (cyclophilins), and Asp f 28 and Asp f 29 (thioredoxins) are homologous to human antigens (cross-reactive pan-allergens) (38). Allergens from other aspergilli has been less investigated. Beendorf et al. (43) identified seven allergens in A. versicolor spores. Recently, Liang at al. (17) identified two proteins (with molecular mass of $43 \mathrm{kDa}$ and $41 \mathrm{kDa}$ ) in A. versicolor, which could be specific for this mould. A. niger and A. oryzae used in industrial

Table 2 Allergens of A. fumigatus

\begin{tabular}{ll}
\hline Allergen & Nature of allergen \\
\hline Asp f 1 & Ribotoxin, major allergen \\
\hline Asp f 2 & Fibrinogen binding protein, major allergen \\
\hline Asp f 3 & Peroxysomal membrane protein \\
\hline Asp f 4 & Unknown \\
\hline Asp f 5 & Metalloproteinase, protein degradation \\
\hline Asp f 6 & Mn-superoxide dismutase, pan-allergen \\
\hline Asp f 7 & Unknown \\
\hline Asp f 8 & Acidic ribosomal protein P2 \\
\hline Asp f 9/ & Cell wall glucanase \\
Crf1 & \\
\hline Asp f 10 & Aspartic endopeptidase, protein degradation \\
\hline Asp f 11 & Cyclophilin, cross-reactive pan-allergen \\
\hline Asp f 12 & Heat-shock protein, hsp 90 \\
\hline Asp f 13 & Alkaline serine protease \\
\hline Asp f 15 & Alkaline serine protease \\
\hline Asp f 16 & Putative glycosylhidrolase \\
\hline Asp f 17 & Galactomannoprotein \\
\hline Asp f 18 & Vacuolar serine protease \\
\hline Asp f 22 & Enolase \\
\hline Asp f 23 & L 3 ribosomal protein \\
\hline Asp f 27 & Cyclophilin, cross-reactive pan-allergen \\
\hline Asp f 28 & Thioredoxin, cross-reactive pan-allergen \\
\hline Asp f 29 & Thioredoxin, cross-reactive pan-allergen \\
\hline Asp f 34 & $\begin{array}{l}\text { PhiA cell wall protein, protease, major } \\
\text { allergen }\end{array}$ \\
\hline
\end{tabular}

fermentations have been recognised as important occupational allergens in baker's asthma (33).

Table 3 shows $A$. alternata allergens. They include the following proteins: aldehyde dehydrogenase, heat shock protein, enolase, ribosomal protein $\mathrm{P} 1$ and $\mathrm{P} 2$, as well as other related uncharacterised proteins (33, 45). Alt a 1 is the major allergen of A. alternata, as more than $80 \%$ of patients allergic to Alternaria spp are sensitised to it $(45,46)$. Recent studies have found homologues of Alt a 1 in the phylogenetically related Stemphylium and Ulocladium species. This suggests that Alt a 1 may not be species-specific $(47,48)$. Several other A. alternata allergens have shown significant cross-reactivity with a closely related mould C. herbarum and with non-fungal species (47). Other worldwide-occurring moulds such as $C$. herbarum and Penicilium spp. are also important sources of allergens for mould-allergic patients (33). Cross-reactivity between the most common allergenic moulds has been presented elsewhere (47-51).

Several studies have shown that germination of Alternaria and Aspergillus spores plays a significant role in allergen release in the environment, including the major respective allergens Alt a 1 and Asp f 1 (32, $52,53)$.

\section{DETECTION OF MOULDS}

\section{Environmental sampling}

Sample collection is an important step in the analysis of indoor moulds. However, optimal sampling methods and standard protocols for routine assessment of mould exposure have not yet been established (54, 55). Generally, there are two techniques for

Table 3 Allergens of A. alternata

\begin{tabular}{ll}
\hline Allergen & Biological activity \\
\hline Alt a 1 & unknown, major allergen \\
\hline Alt a 2 & Aldehyde dehydrogenase, major allergen \\
\hline Alt a 3 & Heat shock 70 protein \\
\hline Alt a 4 & Protein disulfide isomerase \\
\hline Alt a 5 & P2 ribosomal protein \\
\hline Alt a 6 & Enolase \\
\hline Alt a 7 & YCP4 protein \\
\hline Alt a 8 & Mannitol dehydrogenase \\
\hline Alt a 10 & Aldehyde dehydrogenase \\
\hline Alt a 12 & P1 ribosomal protein \\
\hline GP70 & Major allergen \\
\hline
\end{tabular}


bioparticulates: air and surface sampling (56). Air sampling is suitable for determining spore count and viable mould parts $(1,54)$. Settling of bioaerosols depends on the diameter of a particle, and environmental and physical factors (15). Settled dust can be a reservoir of mould spores, their components (conidiophores, hyphae, fine fragments, allergens, glucans), and their metabolites (mycotoxins) accumulated over time $(57,58)$. While air sampling may be a good proxy for recent mould exposure associated with acute symptoms, dust sampling may be a good proxy for long-term exposures, especially in epidemiologic studies $(14,59)$. However, dust sampling does not give information about the potential of contaminants to aeorosolise (57).

\section{Methods}

Traditional methods (culture-based and microscopy) are the primary laboratory tools for mould detection and identification (55). However, these methods have serious limitations. Cultivation-based methods do not identify dead or dormant mould fragments, which also may act as antigens (5). Furthermore, microscopic spore count does not identify smaller fungal fragments and hyphae. Germinated hyphae have higher allergenic activity that fungal conidia; therefore, hyphae significantly affect the air quality of mouldcontaminated buildings $(24,53,57)$. Gorny et al. (24) suggested that spore count should be extended to fungal fragments (24).

In contrast to the traditional methods, molecular and immunological tests may detect all types of mould particles (60). Molecular methods (rDNA and qPCR) do not rely on the viability of organisms and can detect very small quantities of genetic material, which is especially valuable in assessing Aspergillus levels in hospitals (60-62). Pitkäranta et al. (62) suggested that a combination of traditional and molecular tests could give a more comprehensive picture of the fungal flora than any of the methods alone.

Several immunoassays (immunoblotting, Halogen immunoassay, and enzyme-linked immunosorbent assay - ELISA) have been used to identify mould allergens $(31,63)$. The halogen immunoassay is more common in experimental settings to demonstrate how aerosolised fungal fragments and hyphae act as aeroallergens, while the capture ELISA has found more practical application as a tool for detecting mould antigens in real-life (occupational or other) settings $(64,65)$. Commercial ELISAs are available for specific allergens Asp f 1 and Alt a1 and for $A$. versicolor and $S$. chartarum antigens. Due to crossreactive antigens among mould species, speciesspecific tests are recommended for the detection of moulds in various environments $(49,65,66)$. The advantages of immunoassays are the speed, analytical sensitivity, and the possibility to detect a relatively large number of samples in several hours.

\section{ELISA for mould allergens}

The mass fraction of Alt a 1 and Asp $\mathrm{f} 1$ is usually measured in dust samples. The protocols for the $\mathrm{mAb}-$ based Alt a 1 ELISA and mAb/pAb-based assay for Asp f 1 have been described elsewhere (32, 67-69). The limit of detection (LOD) for Asp $\mathrm{f} 1$ is $3.6 \mathrm{ng} \mathrm{g}^{-1}$ to $5.0 \mathrm{ng} \mathrm{g}^{-1}$ and for Alt a $10.12 \mu \mathrm{g} \mathrm{g}^{-1}$ (68-70). So far, no guideline or limit values for these major allergens in dust extracts have been suggested. Salo et al. (64) has proposed a cut-off point of $7 \mu \mathrm{g} \mathrm{g}^{-1}$ for overall Alternaria spp. antigens in household dust.

\section{DETECTION OF ALT A 1 AND ASP F 1}

\section{House dust}

Table 4 shows the levels of Alt a 1 and Asp f 1 in different environments. Neither allergen has been detected in settled dust in urban damp-free homes in Zagreb, Croatia $(68,69)$. Similar results were reported for Alt a 1 and Asp f 1 in several US studies (32, 70, 71) and in Canada (72). Sporik et al. (32), detected Asp f 1 in only $5 \%$ of households (32). These very low frequencies of Alt a 1 and Asp $\mathrm{f} 1$ in household environments may be associated with a relatively low spore count typically found in healthy, non-mouldy houses (71).

\section{Occupational environments}

Unlike households, agricultural settings are usually associated with high exposure to moulds and allergic alveolitis (11). In our recent studies, we detected Alt a 1 and Asp f 1 in $100 \%$ and $62 \%$ of poultry farm dust samples, respectively $(68,69)$. Exposure to Alt a 1 (median Alt a $10.37 \mu \mathrm{g} \mathrm{g}^{-1}$ ) in poultry farms was much higher than to Asp f 1 (median Asp f $117.9 \mathrm{ng} \mathrm{g}^{-1}$ ) (Table 4). Both exposures are relatively low, but we also observed wide ranges of mass fractions of both allergens. This suggests that reservoir dust in poultry farms may become a hazardous secondary source of occupational exposure to these allergens. 
Table 4 Alt a 1 and Asp $f 1$ in settled dust

\begin{tabular}{|c|c|c|c|}
\hline Source & & & Reference \\
\hline & Alt a $1 / \mu \mathrm{g} \mathrm{g}^{-1}$ & $\operatorname{Asp} \mathrm{f} 1 / \mathrm{ng} \mathrm{g}^{-1}$ & \\
\hline Homes, offices & $<$ LOD & $<$ LOD & $68-72$ \\
\hline Poultry farms & 0.37 & 17.9 & 68,69 \\
\hline Sawmill & $<\mathrm{LOD}$ & $>\mathrm{LOD}^{\mathrm{a}}$ & 68 \\
\hline
\end{tabular}

${ }^{a}$ data not presented

$L O D$ - limit of detection

There is little information on mould allergens in other occupational environments. Forestry and wood industry-related workplaces are characterised by high levels of bioaerosols containing moulds. Dillon et al. (56) detected Asp $\mathrm{f} 1$ in air samples taken from a wood chipping facility and suggested it as a suitable marker of exposure to A. fumigatus (56). This study showed that Asp f 1ELISA was sensitive enough to detect airborne Asp f 1 in a sawmill. To my knowledge, fungal allergens have not been measured in other occupational settings.

\section{OTHER INDICATORS OF INDOOR MOULDS}

Mould constituents such as beta-1,3-glucan (57, 73-75), ergosterol (74), and extracellular polysaccharides from Aspergillus and Penicillium (EPS-Asp/Pen) (75) have been used as general markers of fungal biomass. They have been used for exposure assessment to moulds in low-exposure environments and in damp buildings (73-76). In contrast to specific allergens, these indicators do not identify a specific mould.

\section{HEALTH EFFECTS OF MOULDS}

Generally, moulds can affect human health through allergic reactions, infections, and toxic responses (Table 5) (77, 78). Among them, sensitisation and allergic diseases are most commonly associated with inhalation of mould antigens. The major asthmarelated aeroallergen in children and adults worldwide is the genus Alternaria (79-81). Exposure to Cladosporium is associated with allergic respiratory symptoms in children $(14,82)$. The prevalence of mould allergy in atopic individuals is about $20 \%$ to $30 \%$ and up to $6 \%$ in the general population (83). A GA $^{2}$ LEN network survey by Heinzerling et al. (84) showed regional differences in sensitisation to mould allergens, which was higher in the UK and northern Europe than in the Mediterranean countries. Recent studies $(24,43,85-87)$ have extensively investigated the role of indoor fungi such as Aspergillus and Penicillium in the pathogenesis of allergic diseases. A. fumigatus is the cause of $80 \%$ of Aspergillusrelated diseases in humans (78). A. fumigatus-related allergies include rhinitis, allergic asthma, sinusitis, and allergic bronchopulmonary aspergillosis (ABPA) (Table 5). ABPA is a severe complication related to

Table 5 Human diseases and symptoms caused by indoor moulds

\begin{tabular}{|c|c|c|c|}
\hline Category & Diseases & Moulds & Reference \\
\hline Hypersensitivity & Asthma, allergic sinusitis and rhinitis & $\begin{array}{l}\text { Alternaria, } \\
\text { Aspergillus, } \\
\text { Penicillium } \\
\text { Aspergillus }\end{array}$ & $\begin{array}{c}10,14,48,77 \\
11,88\end{array}$ \\
\hline Infection & Aspergilloma & Aspergillus & 77 \\
\hline Invasive infection & $\begin{array}{l}\text { Invasive pulmonary aspergillosis, } \\
\text { invasive rhinosinusitis }\end{array}$ & A. fumigatus & 35,78 \\
\hline Toxic & $\begin{array}{l}\text { Mycotoxicosis (toxins such as aflatoxins, } \\
\text { trichothecenes, gliotoxin, ochratoxin) }\end{array}$ & $\begin{array}{c}\text { Stachybotrys, } \\
\text { Aspergillus }\end{array}$ & $91-93$ \\
\hline $\begin{array}{l}\text { Nonspecific symptoms } \\
\text { (sick building syndrome) }\end{array}$ & $\begin{array}{l}\text { Nasal congestion, itchy and watering eyes, } \\
\text { headache, fatigue, generalised malaise, airway } \\
\text { infections, skin rash }\end{array}$ & various moulds & $59,85,94-97$ \\
\hline
\end{tabular}

${ }^{a}$ Allergic bronchopulmonary aspergillosis 
A. fumigatus sensitisation and colonisation in the lung that affects patients with severe asthma $(35,39,88$, 89). It is a frequent complication in cystic fibrosis patients (90). ABPA patients showed a marked increase in $\mathrm{IgG}$ and $\mathrm{IgE}$ antibodies against special A. fumigatus allergens (35). While recombinant allergens Asp f 4 and Asp $\mathrm{f} 6$ were used in serological diagnosis of ABPA (88), rAsp f 4 was efficient in diagnosis of ABPA in patients with cystic fibrosis (90).

Fungal infection poses a particular risk for immunodeficient patients. Inhaled conidia of $A$. fumigatus may not be efficiently eliminated by immune mechanisms of these patients (38) and may cause life-threatening aggressive infections. Invasive aspergillosis is associated with the colonisation of the lung environment with $A$. fumigatus in immunocompromised patients (leukaemia and bone marrow transplant patients, individuals infected by HIV) $(35,78)$. Hospitals should therefore take particular care to control exposure of immunocompromised patients to this opportunistic mould.

\section{OTHER HEATH EFFECTS OF INHALED INDOOR MOULDS}

Indoor moulds produce mycotoxins that pose a health risk $(10,27,91)$. The production of mycotoxins by building-associated moulds such as Stachybotrys spp., Aspergillus spp., and Penicillium spp. has been well documented, particularly in environments with high concentrations of airborne spores, including farms and compost-handling facilities (11). These mould species produce several mycotoxins such as aflatoxins, trichothecenes, gliotoxin, and ochratoxin (Table 5) (92). Similar to allergens, airborne trichothecene mycotoxins are associated with both spores and small $(<2 \mu \mathrm{m})$ respirable mould particles $(26,27)$. Long-term exposure to living or dead particles containing fungal mycotoxins has been associated with immunsuppression in healthy people (11) and with haematotoxicity, inflammation, and immunosuppression in laboratory animals (93). Jarvis and Miller (92) reported pulmonary mycotoxicosis in farmers exposed to very high quantities of mycotoxins at work.

Table 5 also shows the symptoms associated with poor indoor air quality and sick building syndrome (SBS). The aetiology of SBS is still not clear. Many studies have shown the association between dampness (94), fungal contamination (95), volatile organic compounds $(11,85)$, and building-related illnesses. There is evidence that Penicillium spp. and Aspergillus spp. may play a significant role in $\operatorname{SBS}(96,97)$. Furthermore, inhalation of beta-1,3-glucan from indoor moulds could be associated with non-allergic respiratory symptoms (98). However, Noss et al. (73) suggested that glucan exposure in early childhood can protect against the development of allergy (73). As potent immunological activators, beta-glucans have been recognised to possess a potential to act against several diseases (cancer, diabetes, infectious diseases) and to help patients to recover from chemotherapy and radiotherapy (99).

Further investigations are necessary to find out the role of indoor moulds in aetiology of SBS and other diseases.

\section{CONCLUSION}

Monitoring of mould allergens in reservoir dust may be useful in assessing environmental contamination with moulds. However, due to high cross-reactivity among fungi, only several species-specific mould allergens (Alt a 1 and Asp f 1) have been identified and used in environmental studies. In low-exposure environments determination of dust-borne Alt a 1 and Asp f 1 using ELISA seems to be limited. In bioaerosol-rich environments such as agricultural or wood-industry environments, however, determination of dust-borne Alt a 1 and Asp $\mathrm{f} 1$ may be quite useful in assessing exposure to moulds. Further research should focus on determining mould allergens in air.

\section{Acknowledgement}

Our research referred to in this article was supported by the Ministry of Science, Education and Sports of the Republic of Croatia (grant No. 0220222411-2410).

\section{REFERENCES}

1. Stetzenbach LD, Buttner MP, Cruz P. Detection and enumeration of airborne biocontaminants. Curr Opin Biotechnol 2004;15:170-4.

2. Shelton BG, Kirkland KH, Flanders WD, Morris GK. Profiles of airborne fungi in buildings and outdoor environments in the United States. App Environ Microbiol 2002;68:174353.

3. Górny RL, Dutkiewicz J. Bacterial and fungal aerosols in indoor environment in Central and Eastern European countries. Ann Agric Environ Med 2002;9:17-23. 
4. Jo WK, Seo YJ. Indoor and outdoor bioaerosol levels at recreation facilities, elementary schools, and homes. Chemosphere 2005;61:1570-9.

5. Bartlett KH, Kennedy SM, Brauer M, van Netten C, Dill B Evaluation and a predictive model of airborne fungal concentrations in school classrooms. Ann Occup Hyg 2004;48:547-54.

6. Šegvić Klarić M, Pepeljnjak S. A year-round aeromycological study in Zagreb area, Croatia. Ann Agric Environ Med 2006;13:55-64

7. Ianovici N, Tudorica D. Aeromycoflora in outdoor environment of Timisoara city (Romania). Not Sci Biol 2009;1:21-8.

8. Peternel R, Čulig J, Hrga I. Atmospheric concentrations of Cladosporium spp. and Alternaria spp. spores in Zagreb (Croatia) and effects of some meteorological factors. Ann Agric Environ Med 2004;11:303-7.

9. Pulimood TB, Corden JM, Bryden C, Sharples L, Nasser SM. Epidemic asthma and the role of the fungal mold Alternaria alternata. J Allergy Clin Immunol 2007;120:6107.

10. Cabral JPS. Can we use indoor fungi as bioindicators of indoor air quality? Historical perspectives and open questions. Sci Total Environ 2010;408:4285-95.

11. Fischer G, Dott W. Relevance of airborne fungi and their secondary metabolites for environmental, occupational and indoor hygiene. Arch Microbiol 2003;179:75-82.

12. Horner WE, Worthan AG, Morey PR. Air- and dustborne mycoflora in houses free of water damage and fungal growth App Environ Microbiol 2004;70:6394-400.

13. Pei-Chih W, Huey-Jen S, Chia-Yin L. Characteristics of indoor and outdoor airborne fungi at suburban and urban homes in two seasons. Sci Total Environ 2000;253:111-8.

14. Jacob B, Ritz B, Gehring U, Koch A, Bischof W, Wichmann HE. Indoor exposure to mold and allergic sensitization. Environ Health Perspect 2002;110:647-53.

15. Vesper S, McKinstry C, Haugland R, Neas L, Hudgens E, Heidenfelder B, Gallagher J. Higher environmental relative moldiness index (ERMI ${ }^{\mathrm{sm}}$ ) values measured in Detroit homes of severely asthmatic children. Sci Total Environ 2008;394:192-6

16. Su HJ, Wu PC, Chen HL, Lee FC, Lin LL. Exposure assessment of indoor allergens, endotoxin, and airborne fungi for homes in Southern Taiwan. Environ Res 2001;85:13544.

17. Liang Y, Zhao W, Xu J, Miller JD. Characterization of two related exoantigens from the biodeteriogenic fungus Aspergillus versicolor. Int Biodeter Biodeg 2011;65:21726.

18. Chew GL, Wilson J, Rabito FA, Grimsley F, Iqbal S, Reponen T, Mullenberg ML, Thorne PS, Dearborn DG, Morley RL. Mold and endotoxin levels in the aftermath of hurricane Katrina: A pilot project of homes in New Orleans undergoing renovation. Environ Health Perspect 2006;114:1883-9.

19. Solomon GM, Hjelmroos-Koski M, Rotkin-Ellman MR, Hammond SK. Airborne mold and endotoxin concentrations in New Orleans, Louisiana, after flooding, Octobar through November 2005. Environ Health Perspect 2006;114:13816.

20. McCartney HA, Schmechel D, Lacey ME. Aerodynamic diameter of conidia of Alternaria species. Plant Pathol $1993 ; 42: 280-6$
21. Kildesø J, Würtz H, Nielsen KF, Kruse P, Wilkins K, Thrane U, Gravesen S, Nielson PA, Schneider T. Determination of fungal spore release from wet building materials. Indoor Air 2003;13:148-55.

22. Horner WE, Helbling A, Salvaggio JE, Lehrer SB. Fungal allergens. Clin Microbiol Rev 1995;8:161-79.

23. Reponen T, Grinshpun SA, Conwell KL, Wiest J, Anderson M. Aerodynamic versus physical size of spores: measurement and implication for respiratory deposition. Grana 2001:40:11925.

24. Górny RL, Reponen T, Willeke K, Schmechel D, Robine E, Boissier M, Grinshpun A. Fungal fragments as indoor air biocontaminants. Appl Environ Microbiol 2002;68:352231.

25. Green BJ, Tovey ER, Sercombe JK, Blachere FM, Beezhold $\mathrm{DH}$, Schmechel D. Airborne fungal fragments and allergenicity. Med Mycol 2006;44(Suppl 1):S245-55.

26. Cho SH, Seo SC, Schmechel D, Grinshpun SA, Reponen T. Aerodynamic characteristics and respiratory deposition of fungal fragments. Atmos Environ 2005;39:5454-65.

27. Brasel TL, Douglas DR, Wilson SC, Straus DC. Detection of airborne Stachybotrys chartarum macrocyclic trichothecene mycotoxins on particulates smaller than conidia. Appl Environ Microbiol 2005;71:114-22.

28. Seo SC, Reponen T, Levin L, Grinshpun SA. Size-fractionated $(1 \rightarrow 3)$ - $\beta$-D-glucan concentrations aerosolized from different moldy building materials. Sci Total Environ 2009;407:80614.

29. Reponen T, Seo SC, Grimsley F, Lee T, Crawford C, Grinshpun SA. Fungal fragments in moldy houses: a field study in homes in New Orleans and South Ohio. Atmos Environ 2007;41:8140-9.

30. Meklin T, Reponen T, Toivola M, Koponen V, Husman T, Hyvärinen A, Nevalainen A. Size distributions of airborne microbes in moisture-damaged and reference school buildings of two construction types. Atmos Environ 2002;36:6031-9.

31. Green BJ, Sercombe JK, Tovey ER. Fungal fragments and undocumented conidia function as new aeroallergen source. J Allergy Clin Immunol 2005;115:1043-8.

32. Sporik RB, Arruda LK, Woodfolk J, Chapman MD, PlattsMills TAE. Environmental exposure to Aspergillus fumigatus allergen (Asp f I). Clin Exp Allergy 1993;23:326-31.

33. Kurup VP, Shen HD, Banerjee B. Respiratory fungal allergy. Microbes Infect 2000;2:1101-10.

34. Ronning CM, Fedorova ND, Bowyer P, Coulson R, Goldman G, Kim HS, Turner G, Wortman JR, Yu J, Anderson MJ, Denning DW, Nierman WC. Genomics of Aspergillus fumigatus. Rev Iberoam Micol 2005;22:223-8.

35. Abad A, Fernández-Molina JV, Bikandi J, Ramirez A, Margareto J, Sendino J, Hernando FL, Pontón J, Garaizar J, Rementeria A. What makes Aspergillus fumigatus a successful pathogen? Genes and molecules involved in invasive aspergillosis. Rev Iberoam Micol 2010:27:15582.

36. Latgé JP, Moutaouakil M, Debeaupuis JP, Bouchara JP, Haynes K, Prévost MC. The 18-kilodalton antigen secreted by Aspergillus fumigatus. Infect Immun 1991;59:2586-94.

37. Arruda LK, Mann BJ, Chapman MD. Selective expression of a major allergen and cytotoxin, Asp $\mathrm{f} 1$, in Aspergillus fumigatus. Implications for the immunopathogenesis of Aspergillus related diseases. J Immunol 1992;149:3354-9. 
38. Rementeria A, López-Molina N, Ludwig A, Vivanco AB, Bikandi J, Pontón J. Garaizar J. Genes and molecules involved in Aspergillus fumigatus virulence. Rev Iberoam Micol 2005;22:1-23.

39. Madan T, Priyadarsiny P, Vaid M, Kamal N, Shah A, Haq W, Bandacharya Katti S, Usha Sarma P. Use of a synthetic peptide epitope of Asp f 1, a major allergen or antigen of Aspergillus fumigatus, for improved immunodiagnosis of allergenic bronchopulmonary aspergillosis. Clin Diagn Lab Immunol 2004;11:552-8.

40. Latgé JP. Aspergillus fumigatus and Aspergillosis. Clin Microbiol Rev 1999;12:310-50.

41. Bowyer P, Fraczek M, Denning DW. Comparative genomics of fungal allergens and epitopes shows widespread distribution of closely related allergen and epitope ortologues. BMC Genomics 2006;7:251-64.

42. Glaser AG, Kirsch AI, Zeller S, Menz G, Rhyner C, Crameri R. Molecular and immunological characterization of Asp $\mathrm{f}$ 34, a novel major cell wall allergen of Aspergillus fumigatus. Allergy 2009;64:1144-51.

43. Benndorf D, Müller A, Bock K, Manuwald O, Herbarth O, von Bergen M. Identification of spore allergens from the indoor mould Aspergillus versicolor. Allergy 2008;63:45460.

44. Bush RK, Prochnau JJ. Alternaria-induced asthma. J Allergy Clin Immunol 2004;113:227-34.

45. Asturias JA, Arilla MC, Ibarrola I, Eraso E, González-Rioja R, Martinez A. A sensitive two-site enzyme-linked immunosorbent assay for measurement of the major Alternaria alternata allergen Alt a 1. Ann Allergy Asthma Immunol 2003;90:529-35.

46. Kleine-Tebbe J, Worm N, Jeep S, Mathiessen F, Lowenstein $\mathrm{H}$, Kungel G. Predominance of the major allergen (Alt a 1) in Alternaria sensitized patients. Clin Exp Allergy 1993;23:211-8

47. Postigo I, Gutiérrez-Rodriguez A, Fernández J, Guisantes JA, Suňén E, Martinez J. Diagnostic value of Alt a 1, fungal enolase and manganese-dependent superoxide dismutase in the component-resolved diagnosis of allergy to pleosporaceae. Clin Exp Allergy 2011:41:443-51.

48. Gutiérrez-Rodriguez A, Postigo I, Guisantes JA, Suňén E, Martinez J. Identification of allergens homologous to Alt a 1 from Stemphylium botryosum and Ulocladium botrytis. Med Mycol 2011. (doi:10.3109/13693786.2011.576350)

49. Schmechel D, Simpson JP, Beezhold D, Lewis DM. The development of species-specific immunodiagnostics for Stachybotrys chartarum: The role of cross-reactivity. J Immunol Methods 2006;309:150-9.

50. Kurup VP, Banerjee B. Fungal allergens and peptide epitopes Peptides 2000;21:589-99.

51. Crameri R, Zeller S, Glaser AG, Vilhelmsson M, Rhyner C. Cross-reactivity among fungal allergens: a clinically relevant phenomenon? Mycoses 2008;52:99-106.

52. Mitakakis TZ, Barnes C, Tovey ER. Spore germination increases allergen release from Alternaria. J Allergy Clin Immunol 2001;107:388-90.

53. Green BJ, MitakakisTZ, Tovey ER. Allergen detection from 11 fungal species before and after germination. J Allergy Clin Immunol 2003;111:285-9.

54. Portnoy JM, Barnes CS, Kennedy K. Sampling for indoor fungi. J Allergy Clin Immunol 2004;113:189-98.
55. Tovey ER, Green BJ. Measuring environmental fungal exposure. Med Mycol 2005;43(Suppl 1):S67-70.

56. Dillon KH, Boling DK, Miller JD. Comparison of detection methods for Aspergillus fumigatus in environmental air samples in an occupational environment. J Occup Environ Hyg 2007;4:509-13.

57. Adhikari A, Jung J, Reponen T, Lewis JS, DeGrasse EC, Grimsley LF, Chew GL, Grinshpun SA. Aerosilization of fungi, $(1 \rightarrow 3)-\beta$-D glucan, and endotoxin from flood-affected materials collected in New Orleans homes. Environ Res 2009;109:215-24.

58. Chew GL, Rogers C, Burge HA, Muilenberg ML, Gold DR. Dustborne and airborne fungal propagules represent a different spectrum of fungi with differing relations to home characteristics. Allergy 2003;58:13-20.

59. Laumbach RJ, Kipen HM. Bioaerosols and sick building syndrome: particles, inflammation, and allergy. Curr Opin Allergy Clin Immunol 2005;5:135-9.

60. Goebes MD, Boehm AB, Hildemann LM. Contributions of foot traffic and outdoor concentrations to indoor airborne Aspegillus. Aerosol Sci Technol 2011;45:352-63.

61. Goebes MD, Baron EJ, Mathews KL, Hildemann LM. Effect of building construction on Aspergillus concentrations in a hospital. Infect Control Hosp Epidemiol 2008;29:462-4.

62. Pitkäranta M, Meklin T, Hyvärinen A, Paulin L, Auvinen P, Nevalainen A, Rintala H. Analysis of fungal flora in indoor dust by ribosomal DNA sequence analysis, quantitative PCR, and culture. Appl Environ Microbiol 2008;74:233-44.

63. Green BJ, Schmechel D, Sercombe JK, Tovey ER. Enumeration and detection of aerosolized Aspergillus fumigatus and Penicillium chrysogenum conidia and hyphae using a novel double immunostaining technique. J Immunol Methods 2005;307:127-34.

64. Salo PM, Arbes SJ Jr, Crockett PW, Thorne PS, Cohn RD, Zeldin DC. Exposure to multiple indoor allergens in US homes and its relationship to asthma. J Allergy Clin Immunol 2008;121:678-84.

65. Schmechel D, Green BJ, Blachere FM, Janotka E, Beezhold DH. Analytical bias of cross-reactive polyclonal antibodies for environmental immunoassays of Alternaria alternata. J Allergy Clin Immunol 2008;121:763-8.

66. Schmechel D, Simpson JP, Lewis DM. The production and characterization of monoclonal antibodies to the fungus Aspergillus versicolor. Indoor Air 2005;15(Suppl 9):11-9.

67. Abebe M, Kumar V, Rajan S, Thaker A, Sevinc S, Vijay HM. Detection of recombinant Alt al in a two-site, IgM based, sandwich ELISA opens up possibilities of developing alternative assays for the allergens. J Immunol Methods 2006;312:111-7.

68. Prester Lj, Macan J. Determination of Alt a 1 (Alternaria alternata) in poultry farms and a sawmill using ELISA. Med Mycol 2010;48:298-301.

69. Prester Lj, Macan J, Matković K, Vučemilo M. Determination of Aspergillus fumigatus allergen 1 in poultry farms using the enzyme immunoassay. Arh Hig Rada Toksikol 2010;61:167-73.

70. Ryan TJ, Whitehead LW, Connor TH, Burau KD. Survey of the Asp f 1 allergen in office environments. Appl Occup Environ Hyg 2001;16:679-84.

71. Vailes L, Sridhara S, Cromwell O, Weber B, Breitenbach M, Chapman M. Quantitation of the major fungal allergens, 
Alt a 1 and Asp f 1, in commercial allergenic products. J Allergy Clin Immunol 2001;107:641-6.

72. Loo CK, Foty RG, Wheeler AJ, Miller JD, Evans G, Stieb DM, Dell SD. Do questions reflecting indoor air pollutant exposure from a questionnaire predict direct measure of exposure in owner-occupied houses? Int J Environ Res Public Health 2010;7:3270-97.

73. Noss I, Wouters IM, Bezemer G, Metwali N, Sander I, RaulfHeimsoth M, Heederik DJJ, Thorne PS, Doekes G. $\beta-(1,3)-$ Glucan exposure assessment by passive airborne dust sampling and new sensitive immunoassays. Appl Environ Microbiol 2010;76:1158-67.

74. Foto M, Vrijmoed LLP, Miller JD, Ruest K, Lawton M, Dales RE. A comparison of airborne ergosterol, glucan and Air-OCell data in relation to physical assessments of mold damage and some other parameters. Indoor Air 2005;15:257-66.

75. Douwes J, Siebers R, Wouters IM, Doekes G, Fitzharris P, Crane J. Endotoxin, $(1 \rightarrow 3)-\beta$-D-glucans and fungal extracellular polysaccharides in New Zealand homes: a pilot study. Ann Agric Environ Med 2006;13:361-5.

76. Salare VR, Hinde CA, Miller JD. Analysis of settled dust in homes and fungal glucan in air particulate collected during HEPA vacuuming. Indoor Built Environ 2009;18:485-91.

77. Park SJ, Mehrad B. Innate immunity to Aspergillus species. Clin Microbiol Rev 2009;22:535-51.

78. Latgé JP. The pathobiology of Aspergillus fumigatus. Trends Microbiol 2001;9:382-9.

79. Osborne M, Reponen T, Adhikari A, Cho SH, Grinshpun SA, Levin L, Bernstein DI, LeMasters G. Specific fungal exposures, allergic sensitization, and rhinitis in infants. Pediatr Allergy Immunol 2006;17:450-7.

80. Salo PM, Arbes SJ Jr, Sever M, Jaramillo R, Cohn RD, London SJ, Zeldin DC. Exposure to Alternaria alternata in US homes is associated with asthma symptoms. J Allergy Clin Immunol 2006;118:892-8.

81. Stark PC, Celedón JC, Chew GL, Ryan LM, Burge HA, Muilenberg ML, Gold DR. Fungal levels in the home and allergic rhinitis by 5 years of age. Environ Health Perspect 2005;113:1405-9.

82. Gent JF, Ren P, Belanger K, Triche E, Bracken MB, Holford TR, Leaderer BP. Levels of household mold associated with respiratory symptoms in the first year of life in a cohort at risk for asthma. Environ Health Perspect 2002;110:A7816.

83. Wüethrich B. Epidemiology of allergic diseases: are they really on the increase? Int Arch Allergy Appl Immunol 1989:90(Suppl 1):3-10.

84. Heinzerling L, Frew AJ, Bindslev-Jensen C, Bonini S, Bousquet J, Bresciani M, Carlsen KH, van Cauwenberge P, Darsow U, Fokkens WJ, Haahtela T, van Hoecke H, Jessberger B, Kowalski ML, Kopp T, Lahoz CN, Lodrup Carlsen KC, Papadopoulos NG, Ring J, Schmid-Grendelmeier P, Vignola AM, Wöhrl S, Zuberbier T. Standard skin prick testing and sensitization to inhalant allergens across Europe - a survey from the $\mathrm{GA}^{2} \mathrm{LEN}$ network. Allergy 2005;60:1287300.

85. Pasanen P, Korpi A, Kalliokoski P, Pasanen AL. Growth and volatile metabolite production of Aspergillus versicolor in house dust. Environ Int 1997;23:425-32.

86. Pongracic JA, O'Connor GT, Muilenberg ML, Vaughn B, Gold DR, Kattan M, Morgan WJ, Gruchalla RS, Smartt E, Mitchell HE. Different effects of outdoor versus indoor fungal spores on asthma morbidity in inner-city children. J Allergy Clin Immunol 2010;125:593-9.

87. Katz Y, Verleger H, Barr J, Rachmiel M, Kiviti S, Kuttin ES. Indoor survey of moulds and prevalence of mould atopy in Israel. Clin Exp Allergy 1999;29:186-92.

88. Crameri R, Blaser K. Allergy and immunity to fungal infections and colonization. Eur Respir J 2002;19:151-7.

89. Crameri R, Hemmann S, Ismail C, Menz G, Blaser K. Disease-specific recombinant allergens for the diagnosis of allergic bronchopulmonary aspergillosis. Int Immunol 1998;10:1211-6.

90. Fricker-Hidalgo H, Coltey B, Llerena C, Renversez JC, Grillot R, Pin I, Pelloux H, Pinel C. Recombinant allergens combined with biological markers in the diagnosis of allergic bronchopulmonary aspergillosis in cystic fibrosis patients. Clin Vaccine Immunol 2010;17:1330-6.

91. Nielsen KF. Mycotoxin production by indoor molds. Fungal Genet Biol 2003;39:103-17.

92. Jarvis BB, Miller JD. Mycotoxins as harmful indoor air contaminants. Appl Microbiol Biotechnol 2005;66:367-72.

93. Piecková E, Hurbánková M, Černá S, Lišková A, Kováčiková Z, Kolláriková Z, Wimmerová S. Inflammatory and haematotoxic potential of indoor Stachybotrys chartarum (Ehrenb.) hughes metabolites. Arh Hig Rada Toksikol 2009;60:401-9.

94. Saijo Y, Nakagi Y, Ito T, Sugioka Y, Endo H, Yoshida T. Relation of dampness to sick building syndrome in Japanese public apartment houses. Environ Health Prev Med 2009;14:26-35.

95. Li D, Chin S. Yang. Fungal contamination as a major contributor to sick building syndrome. Adv Appl Microbiol 2004;55:31-112.

96. Schwab CJ, Straus DC. The roles of Penicillium and Aspergillus in sick building syndrome. Adv Appl Microbiol 2004;55:215-38.

97. Hiipakka DW, Buffington JR. Resolution of sick building syndrome in a high-security facility. Appl Occup Environ Hyg 2000:15:635-43.

98. Douwes J. $(1 \rightarrow 3)-\beta$-D-glucans and respiratory health: a review of the scientific evidence. Indoor Air 2005;15:1609.

99. Chen J, Seviour R. Medicinal importance of fungal $\beta-(1 \rightarrow$ 3), (1 $\rightarrow$ 6)-glucans. Mycol Res 2007;111:635-52. 


\section{Sažetak}

\section{IZLOŽENOST ALERGENIMA PLIJESNI U UNUTARNJEM OKOLIŠU}

Vlažni, unutarnji prostori mogu biti kolonizirani alergogenim, filamentoznim mikrogljivicama (plijesni) uglavnom rodova Aspergillus, Penicillium, Cladosporium i Alternaria. Respiratorne bolesti uzrokovane plijesnima zdrastveni su problem diljem svijeta. U posljednja dva desetljeća, neki sastavni dijelovi plijesni kao alergeni i glukan rabe se kao pokazatelji izloženosti plijesni u unutarnjem okolišu. Nedavno su alergeni plijesni Alt a 1 (Alternaria alternata) i Asp f 1 (Aspergillus fumigatus) određivani u različitom okolišu (kućnom i profesionalnom) enzim-imunokemijskom metodom koja rabi monoklonska ili poliklonska antitijela. Razina Alt a 1 i Asp f 1 u kućnoj prašini ispod je granice detekcije. Nasuprot tomu, alergeni plijesni su određeni u okolišu s visokom razinom bioaerosola kao peradarnici i pilane. Razine alergena Alt a 1 i Asp f 1 u nekim poljoprivrednim objektima pružaju informaciju o mogućoj kolonizaciji plijesnima, što upućuje na moguće zdravstvene učinke kod zaposlenika.

KLJUČNE RIJEČI: Alt a 1, Asp f 1, A. alternata, A. fumigatus, ELISA, profesionalna izloženost

\section{CORRESPONDING AUTHOR:}

Ljerka Prester

Institute for Medical Research and Occupational Health

Ksaverska c. 2, 10000 Zagreb, Croatia

E-mail:prester@imi.hr 